RAND RESEARCH AREAS

THE ARTS

CHILD POLICY

CIVIL JUSTICE

EDUCATION

ENERGY AND ENVIRONMENT

HEALTH AND HEALTH CARE

INTERNATIONAL AFFAIRS

NATIONAL SECURITY

POPULATION AND AGING

PUBLIC SAFETY

SCIENCE AND TECHNOLOGY

SUBSTANCE ABUSE

TERRORISM AND

HOMELAND SECURITY

TRANSPORTATION AND

INFRASTRUCTURE

WORKFORCE AND WORKPLACE

This product is part of the RAND Corporation research brief series. RAND research briefs present policy-oriented summaries of published, peer-reviewed documents.

Corporate Headquarters 1776 Main Street P.O. Box 2138

Santa Monica, California

90407-2138

TEL 310.393.0411

FAX 310.393 .4818

(c) RAND 2008

www.rand.org

\title{
Assessing the New York City Police Department Firearm Training and Firearm-Discharge Review Process
}

W

hen it comes to enforcing laws and protecting communities, society grants police officers special powers to apply force, including deadly force. Still, police officers are taught that deadly force is a last resort to protect someone from imminent death or serious injury. To ensure that his department was minimizing unnecessary firearm discharges, New York City Police Commissioner Raymond Kelly asked the RAND Corporation to study the issue.

In 2007, RAND researchers talked with New York City Police Department (NYPD) plainclothes and uniformed officers, collected and reviewed policy documents, and examined relevant general literature on policing, use of force, and reflexive and contagious shooting. The team also analyzed firearm-discharge cases; NYPD personnel data; stop, question, and frisk report data; and data from the automated, online booking system. Finally, the team collected information from other police departments and sponsored a daylong discussion of the issues with a panel of independent national experts. This research brief summarizes key findings and recommendations.

\section{Training}

Training consists of basic recruit training and in-service training. Overall, the team found that basic policing-skills training adhered to modern principles and standards of effective adult learning but that training in complex policing skillsthose that integrate law and policy, effective communication, decisionmaking, and tactics—could be improved. The nine weeks of recruit training devoted to hands-on, complex policing skills is largely done in scenario-based, role-playing workshops or with simulators, which have become the nationally accepted norm for teaching these subjects. However, the logistics of these workshops

\section{Abstract}

This research brief summarizes the results of an objective, comprehensive assessment of the NYPD firearm training and firearmdischarge review process. It provides findings and recommendations on training, discharge investigations and reporting, factors associated with officers who discharge their firearms, the need for improved less-than-lethal standoff weapons and other innovative technologies, and reflexive shootings.

and the size of the recruit-training class mean that some students might not have fully mastered all lessons before having to move on to the next class. Alternative arrangements could allow each student to progress at his or her own pace. The new NYPD Training Academy facility will also provide a more appropriate training environment to carry out this kind of training.

NYPD officers must also requalify on their firearms twice a year. This is now done by shooting at static targets, but new courses being developed at NYPD, which require officers to shoot at moving targets, from crouched positions, and after exertion, are more likely to reflect realworld situations. While moving 37,000 officers through the firearm requalification course every six months is logistically challenging, remedial training should be provided to officers who demonstrate poor firearm techniques, even if they achieved a passing score.

Based on these findings, the authors recommend increasing the recruits' exposure to scenario-based training and evaluating and not passing them until they demonstrate skill mastery at an appropriate level. They also recom- 
mend investigating alternatives to the current semiannual firearm-requalification paradigm to provide enhanced firearm instruction that would focus on the officer's proficiency, not just the score on static targets.

\section{Firearms Discharge Review Board Investigation and Reporting}

Based on the review of national best practices, NYPD has a number of exemplary features, including substantial and appropriate command attention at the incident scene (the nature of which varies with incident seriousness) and a process that generally results in reasoned disciplinary action where appropriate.

To improve the current process, the authors recommend (1) expanding the focus to include a formal review of the tactics involved, including whether officers unnecessarily gave themselves no choice but to fire their weapons; (2) formally developing lessons learned that could be disseminated to all officers; (3) better responding to key investigative questions, such as whether less-than-lethal force options were available; and (4) providing more synthesis in final reports-i.e., more analysis and less fact.

\section{Factors Associated with NYPD Officers Discharging Firearms}

While the average NYPD officer is very unlikely to be involved in a shooting ( 0.26 percent annually), the authors found-matching actual shooting officers with those nonshooting officers near the scene of shooting incidents- that they could statistically determine that certain officer characteristics are associated with a higher risk of being involved in a shooting. Shooting officers tended to be younger, get more medals, accumulate more negative marks in their files (referred to as Central Personnel Index [CPI] points), make more felony arrests, be injured in the line of duty, have more complaints filed against them, and have special, nonpatrol-officer assignments. These characteristics describe a more assertive officer, one who can do heroic actions and garner medals and simultaneously perform actions that warrant negative marks. Since the vast majority of officers who shared these same characteristics never discharged their weapons, it was not possible to use this analysis as a screening tool before the fact. Given this finding, the authors recommend that the
NYPD pay particular attention when investigating shootings involving officers with an annual CPI-point average in excess of 3.1 to make sure that those officers did everything appropriate before discharging their firearms. While the NYPD already monitors those officers exceeding a career total of 20 CPI points, closer monitoring of officers with a high accumulation rate of CPI points may also be warranted.

\section{Need for Improved Less-Than-Lethal Standoff Weapons and Other Innovative Technologies}

Analysis of the NYPD firearm-discharge cases and the experience of other police departments suggest that, if the NYPD had a broader deployment of a more robust less-than-lethal standoff weapon, such as TASER ${ }^{\bullet}$ devices, it not only might prevent some incidents from escalating to deadly force but might also reduce injuries to officers and citizens alike, as has been the case in other departments. While the NYPD does provide pepper spray to all patrol officers and TASER devices to patrol supervisors on a limited basis, the authors recommend that the NYPD implement a pilot program that expands the current availability of TASER devices to all patrol officers in selected precincts.

Also, given the potential of laser sights and handgunmounted flashlights, the authors recommend a test of laser sights with plainclothes officers followed by a pilot study with uniformed officers and a pilot test of handgun-mounted flashlights.

\section{Reflexive Shooting}

Data on intentional reflexive discharges (or contagious shootings) are not readily available, neither within NYPD nor across departments, which means that the team could not determine the extent of reflexive shootings or whether they are increasing or decreasing over time. Still, given that they occur, the team recommends that the NYPD modify training to include reflexive-shooting scenarios in which a stimulus or the sounds of guns going off are included, to sensitize officers to cues that may not be reliable and to teach them that such cues may generate unwanted responses; have officers practice with the correct decisionmaking process to reduce the use of inappropriate decisionmaking shortcuts; and ensure that all officers in a shooting undergo the mandatory one-day range refresher course. -

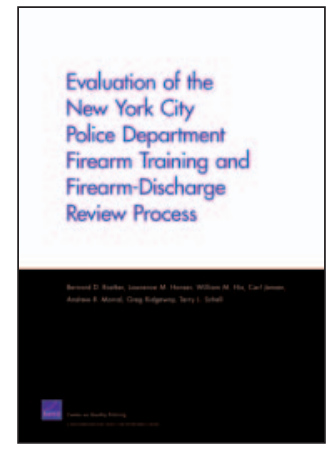

This research brief describes work done for the RAND Center on Quality Policing documented in Evaluation of the New York City Police Department Firearm Training and Firearm-Discharge Review Process, by Bernard D. Rostker, Lawrence M. Hanser, William M. Hix, Carl Jensen, Andrew R. Morral, Greg Ridgeway, and Terry L. Schell, MG-717-NYPD (available at http://www.rand.org/ pubs/monographs/MG717//, 2008, 142 pp., \$29.50, ISBN: 978-0-8330-4416-7. The RAND Corporation is a nonprofit research organization providing objective analysis and effective solutions that address the challenges facing the public and private sectors around the world. RAND's publications do not necessarily reflect the opinions of its research clients and sponsors. RAND ${ }^{\circledR}$ is a registered trademark.

RAND Offices

Santa Monica, CA • Washington, DC • Pittsburgh, PA • Jackson, MS/New Orleans, LA • Doha, QA • Cambridge, UK • Brussels, BE 


\section{RAND Center on Quality Policing}

A RAND INFRASTRUCTURE, SAFETY, AND ENVIRONMENT CENTER

THE ARTS

CHILD POLICY

CIVIL JUSTICE

EDUCATION

ENERGY AND ENVIRONMENT

HEALTH AND HEALTH CARE

INTERNATIONAL AFFAIRS

NATIONAL SECURITY

POPULATION AND AGING

PUBLIC SAFETY

SCIENCE AND TECHNOLOGY

SUBSTANCE ABUSE

TERRORISM AND HOMELAND SECURITY

TRANSPORTATION AND

INFRASTRUCTURE

WORKFORCE AND WORKPLACE
This PDF document was made available from www.rand.org as a public service of the RAND Corporation.

This product is part of the RAND Corporation research brief series. RAND research briefs present policy-oriented summaries of individual published, peerreviewed documents or of a body of published work.

The RAND Corporation is a nonprofit research organization providing objective analysis and effective solutions that address the challenges facing the public and private sectors around the world.

\section{Support RAND}

Browse Books \& Publications

Make a charitable contribution

\section{For More Information}

\author{
Visit RAND at www.rand.org \\ Explore the RAND Center on Quality Policing \\ View document details
}

Limited Electronic Distribution Rights

This document and trademark(s) contained herein are protected by law as indicated in a notice appearing later in this work. This electronic representation of RAND intellectual property is provided for non-commercial use only. Unauthorized posting of RAND PDFs to a non-RAND Web site is prohibited. RAND PDFs are protected under copyright law. Permission is required from RAND to reproduce, or reuse in another form, any of our research documents for commercial use. For information on reprint and linking permissions, please see $\underline{\text { RAND Permissions. }}$ 